\title{
Bahr Al-Madhi: Significant Hadith Text Sciences for Malay Muslims as a Tool for Political Teaching during Twentieh Century
}

\author{
Assoc. Prof Dr. Latifah Abdul Majid \\ Department of al-Quran and al-Sunnah Studies \\ umilm@yahoo.co.uk \\ Assoc. Prof. Dr Nurullah Kurt \\ International Affairs, University of Technology Malaysia \\ kurtnurullah@hotmail.com.tr
}

Doi:10.5901/mjss.2014.v5n20p2249

\begin{abstract}
This article focuses on specific Hadith text, Bahr al-Madhi al-Sharh Mukhtasar Sahih al-Tirmidhi by Shaikh Idris al-Marbawi. This text is selected for two reasons: firstly, its provide invaluable data for analyses of political teaching in Malaysia (particularly during 20th century); secondly, its were openly acknowledged by the Malay community until recently as highly esteemed sources of revelation from the Prophet (p.b.h), but may now be neglected in favour of more 'modern' versions. The research is therefore undertaken on a three-fold premise, as follows: this text should be restored to their former status as clear and authoritative guides for human conduct in areas ranging from manners to political teaching. Al-Marbawi's commentary provides the clearest examples of the use of exegesis as a tool for political teaching, and its written methodology is held to have influenced the great Hadith scholar - al-Tirmidhi - and should therefore be esteemed accordingly. The intention in this is to demonstrate al-Marbawi's deep condemnation at that time of the misconduct of leadership for instance. Therefore, as a criticism of this behaviour, his condemnation is significantly absolute. In the course of history however this condemnation may have been forgotten. One of the main purposes of this study is thus to act as a reminder. In the light of his strong influence upon such esteemed Hadith scholars as al-Tirmidhi, it is argued that the writings of al-Marbawi represent a vital resource for the purposes of educating the Malay people on the subject of the Hadith. In the interests of validity and reliability, the study provides multiple sources of evidence. These include tape-recorded in-depth interviews with researchers (in particular with an expert educationalist in 20th century social, political and religious affairs in Malaysia) and academicians who are biographers of this great scholar identified. Also included are data-gathering techniques such as library and document research. Research methods used to examine the original writings of al-Marbawi are largely 'qualitative', and consist of approaches such as 'hermeneutics and the 'inferential' technique of 'content analyses'.
\end{abstract}

\section{Introduction}

In Islam, politics was an important part of life that religious leaders had to participate in. Therefore, Bahr al-Madhi of alMarbawi demonstrates clearly 'a political model' which is rooted in the purity of the truth as declared by the Prophetic Hadith.

The Hadith text of al-Marbawi (Bahr al-Madhi) provides a guide to the political teaching which governs a Muslim society. The author therefore devotes his writing to an explanation of this political teaching which stress several important elements: such as the role of the rulers and obedience to him, and the meaning of jihad in a Malaysian context.

However, it should be stated here that a detailed discussion of the significance of Bahr al-Madhi political teaching is beyond the scope of this subject and therefore will not be scrutinized in this topic. Nevertheless, as an appreciation of the role and its meaning for Malay readers, it will be helpful here to discuss several current issues which specifically relate to al-Marbawi analysis of political aspects in his work.

\section{The Importance of Bahr Al-Madhi and for Malaysian Readers}

Al-Marbawi has discussed and commented on the Hadith on dogmatic ('aqacid), legal rules, moral teachings, proper manners (al-adab), Qur'anic commentary, history and biography of the Prophet (al-tafsir wa al- tarikh wa al-siyar), seditions and crises (al-fitan), and virtues (manaqib) defects (matalib) as in al-Tirmidhi's work. The importance of alMarbawi's contribution to Islamic scholastic tradition here is that he was the first to embark upon a comprehensive 
translation into Malay of al-Tirmidhi's Jamic, elaborated with detailed commentaries across all the areas detailed above.

It can be seen, then, from the content of the text that the clarity with which al-Marbawi has dealt with all areas of human conduct makes his teachings a vital tool for religious, social and political discourse in contemporary Malaysia (Wan Sabri Wan Yusuf, Shayuthi Abdul Manaf \& Nadzirah binti Muhammad, Shaykh Mustafa Abdul RahmanMahmud 1918-1968). According to Fauzi and Ngah, this is particularly the case since among the purposes of the translations and commentaries of Arabic texts was the definition of an ideal Islamic society and, importantly, indications of the ways in which Malays fall short of this ideal (Fauzi Deraman 1999:163-173). In line with this argument, Bernard Lewis, (Lewis,Bernard 1988:565-583) for example, has stated that the contemporary translations are examples of what he terms an 'authoritarian and quietist' mode of Malay Muslim practical thought (M.R.Woodward 1993). Therefore, in the context of Malaysian political culture this author adopt this method to seek to restructure the Malay Muslim society into the ideal Islamic society based on the Hadith of the Prophet (Mohd Nor Ngah 1983: 366-392).

Hence, in the Bahr al-Madhi's text, the 'introduction' is replaced by a brief statement explaining the significance of this text for Malay readers. Al-Marbawi, for example, first stated his great respect for al-Tirmidhi's work; portraying him as a great Hadith scholar who was blessed by Allah (S.W.T) with skill in Hadith scholarship (Al-Marbawi :5-8).

Al-Marbawi next gives a brief biography of cUmar ibn al-Khattab (from the Prophet's life to the time of Umar's Caliphate), followed by an evaluation of Umar's position in the Islamic movement (Al-Marbawi :5-8). cUmar is described as a great scholar who was blessed by Allah with skill in leadership, an excellent juristic judgement and in Islamic knowledge, who was a pivotal figure in the history of Islam (the Sassanid and Byzantine [Roman] empires). While alMarbawi analyzes his decisions primarily in military and political terms, he is nevertheless also concerned with the religious or character judgments that interest Muslims (Al-Marbawi :5-8). .

In a same way, his intention is also that at the same time the Malay community may understand the background, the leadership and 'sainthood' of 'Umar precisely, as is shown in the following description on 'Umar's life (Al-Marbawi :58):

For your information my brothers! CUmar al-Khattab was the second Caliph and he was from the Banu 'Adi clan of the Quraysh tribe. He was born in Mecca. His father was Khattab ibn Nufayl, and he is said to have belonged to a middle class family. He was literate, which by some accounts is considered to be uncommon in those times, and he was also well known for his physical strength, being a champion wrestler Bahr al-Madhi).

Woodward believes that "the appearance of extraordinary abilities at an early age is a common theme in Malay biographical myth and is often attributed to divine intervention" (M.R.Woodward 1993). Politicians, leaders, and religious scholars for example are often said to have shown signs of greatness and divine inspiration as children. In addition, Woodward has pointed out that "the ability to memorize the Qur'an and Hadith without years of effort is thus held to be a gift from Allah and a sign of sainthood" (M.R.Woodward 1993).Therefore, for Malay readers, these personal qualities establish the sacred character of al-Tirmidhi's work and link him with local concepts of sainthood.

In this way, al-Marbawi does not discuss criticism al-Tirmidhi's concerning the conduct of the reigning Caliphate (http://www.sunnah.org/history/Scholars/imam_tirmidhi.htm). As stated above, al-Marbawi confirms his neglecting of 'practical politics', as only those biographical aspects of the work of Tirmidhi and 'Umar are selected in his work. This, however, does not mean that the participation of al-Tirmidhi in a 'fundamental activist' mode of Islamic politics did not influence al-Marbawi's works at all. Al-Marbawi's citation of al-Tirmidhi works (Hadith) in his call for support to reshape society in Malaysia are closely interrelated. In this sense, 'Kaum Tua groups' ignore those elements which could be used to propose an alternative or radical activist discourse, in contrast to 'Kaum Muda groups'. The key point to address here however is not which group is 'right' or 'wrong', but that al-Marbawi sought to achieve unity for the Malay people, based on the purity of the Hadith.

Woodward believes that the Malay text therefore "combines these approaches by establishing analogies between events in the early history of Islam and contemporary life and emphasizing the meanings of the text" (M.R.Woodward 1993). Similarly, here al-Marbawi states that the types and qualities of blessing available to the early Muslim community can still be obtained.

It is clear that al-Marbawi decidedly seek to present the prominent Hadith scholar al-Tirmidhi, to the readers of his translation or commentary through the preservation of al-Tirmidhi's Hadith. The Malay Muslim community and students of Hadith in Malaysia are able to continue to gain knowledge of the Hadith of al-Tirmidhi without doubt.

\section{The Duties and Responsibilities of the Rulers}

Bahr al-Madhi stress the responsibilities of the rulers or Sultan to their sultanate as well the responsibility of the sultanate to their rulers. 
Rahim, noted that during the nineteenth century, the political standpoint of Malaysia was governed by several main groups; "the Malay rulers (Sultans), the Malay aristocrats, the ulama (religious scholars) and the British colonial" (Rahimin Affandi Abd. Rahim 2006:93-104) The former two groups constituted the 'upper class' in Malay society and their living standards were far ahead of those of the middle class and the Malay peasantry. This 'upper class' dominated most of the government positions, but neglected the welfare and development of their society (llya Romiza, Za'ba :137).

Therefore, al- Marbawi was critical of the negative role of this group in Malay society, and of their indifference to the discrimination against fellow Malays in their country. For this reason al- Marbawi's early writings condemned the Malay rulers for leading extravagant and self indulgent lives in their own 'palaces', while the Malay commoners lived in poverty and were left far behind the immigrants.

Such behaviour is clearly unacceptable within the Malay-Islamic political tradition; justice must become the basic requirement for the legitimacy of a Malay sultanate, in line with the principles of the Hadith. El-Edrus stated that this emphasis on justice is demonstrated in the traditional swearing-in ceremony at the installation of Malay Sultans, where they have to swear to do their utmost to rule justly by saying: wa-Allahi, wa-ta-Allahi, wa-bi-Allahi' (Al-Edrus 1995:65).

In addition, under section 'Bab ma ja'a fi al-Imam al-cAdil' al-Marbawi demonstrates (for example) that the Sultan or rulers of the Muslim society must strive to:

1. Establish justice (including the punishment of crime) among the people.

2. Preserve Islam in its original form, and defend against the introduction into Islam of heretical beliefs (bid cah).

3. Ensure the protection of society. Those within the borders of the Muslim state (whether they are Muslims or not) should feel sufficiently secure to be productive members of the communities contained by Islam

4. Secure the physical borders of the state, using arms and other defensive measures.

\section{The Obligation of Obedience to the Rulers}

Bagley, who discusses matters 'with reference to counsellors of the sultanate' as stated by Hefner and Patricia, affirms that "the ulama's positions in terms of political power are varied throughout Islamic history, for example al-Ghazali in his 'Nasihat al-Muluk' wrote that the Sultan was 'God's Shadow on Earth"(F.R.Bagley 1964 and W.Hefner and Patricia Horvatich 1997:p.10), and was the Lord's delegate over his creatures and must therefore be held in high regard. AlGhazali also 'stigmatized' any form of rebellion, even if this was against an oppressive and evil monarch. For al-Ghazali (F.R.Bagley 1964 and W.Hefner and Patricia Horvatich 1997:p.10) Muslims must do nothing in the face of such oppression and evil, but must instead keep bitter thoughts in their hearts" (Massino Campanini 2002:260) In this way, social peace and harmony can be achieved in the outer world. Thus, war and violence should be avoided at all costs even in the face of an autocratic rule (Al-Marbawi vol.13:105)

Therefore, in line with same view of al-Ghazali, we can see in earlier Malay Hadith texts (al-Raniri and al-Sinki) that the Sultan is considered to be a 'shadow of Allah upon the earth'. Thus, according to Malay Muslim scholars, obedience to the Sultan or King is fard kifayah (Mohd. Nor Ngah :36 and Zayn al-cAbidin Muhammad al-Fatani 1890:362).

Thus, in dealing with the obligation of obedience to the rulers in Malaysia, Malay religious scholars for example alMarbawi adopted the al-Ghazalian approach which means that it was the duty of the people to be loyal to the Sultan, (Mohamed Nawab) and not to commit treason because this represented an act 'against God' (T. Iskandar and Nuruddin Ar-Raniri's Bustanu's Salatin 1966:46).

Al-Marbawi is therefore careful to point out in his commentary that if the Sultan or ruler governs wisely according to the commandment of the Qur'an and the Hadith, then the people must show him allegiance and support him. On the other hand, if he becomes unjust, or is so handicapped as to become ineffective (for example through blindness or amputation), then he may be justly and lawfully removed, but not through force or arms (Al-Marbawi vol.10:41)

\section{Disobedience to the Rulers}

In line with this, al-Marbawi states that disobedience is only permissible in the event that the ruler's decision is clearly contrary to the Qur'an and the Hadith, as he states:

\section{Allah revealed: 0 you who believe! Obey Allah and obey the Messenger and those who are in authority (uli al-amr) ( Al-} Qur'an, 4:59).

Although al-Marbawi counsels support for the Sultan, he warns him that he must not rule unjustly. Thus, in political affairs, al-Marbawi sternly warns that the ruler is worthy of support only if he is 'just and honest' as the Prophet 
commands:

It is obligatory upon a Muslim to listen (to the ruler) and obey whether he likes it or not, except when he is ordered to do a sinful thing; in such case, there is no obligation to listen or to obey.

This Hadith 'crystallizes the parameters' of obedience which is due to Muslim rulers. From this standpoint, the honour of the ruler is inextricably linked to his surrender to the Command of Allah and His Messenger (s.a.w). Otherwise, apart from condemnation in the Hereafter, he will also suffer humiliation in this world. Thus, according to al-Marbawi, obedience to a Muslim ruler demands two conditions:

i) First, his command must not violate the Holy law of the Qur'an and the Hadith;

ii) Second, he must command of the subject only what is possible.

If, however, the ruler fails to meet these two conditions then obedience to his will also cease to be obligatory (AlMarbawi vol.12:12) It is because of these two conditions that this Hadith sends a warning to rulers that they must not submit people to unbearable hardship. Obedience to a ruler is essential to the collective interests of the community.

\title{
6. Forbidden to Ask for Positions of Authority
}

In this commentary al-Marbawi also warns against those rulers who seek their position of authority through ambition as the Prophet declares:

\begin{abstract}
Whoever asks for a position of authority and is given it as a result of that request, will be left alone as its captive. If he is granted this position without asking for it, he will be helped (by Allah) in discharging its responsibilities (Al-Marbawi vol.10:37).
\end{abstract}

For al-Marbawi, by the term 'rulers' is meant caliphate or any other rank affiliated to its hierarchy. Yet, it is not desirable to strive for such high position as it brings with it a heavy responsibility and one may not abdicate or be absolved from it.

However, if a man is offered this high position without solicitation, he should accept it. This Hadith therefore urges Muslims (particularly those who do not have enough ability) to abandon the ambition of achieving dominion and power. It is feared by al-Marbawi that because of their lack of wisdom they will manage badly the task assigned to them, and that will render them guilty in the sight of Allah.

This Hadith thus backs the idea presented by al- Marbawi, that a person putting himself forward for office should be deprived of it. This is in line with his view that ambitious persons who manage to obtain high office, damage the interests of others. In his opinion, a government should aim primarily at the welfare of the people, not serve the interests of a privileged few or benefit merely the holders of key posts.

\section{The Prerequisites TO Becoming Rulers}

Al- Marbawi also emphasizes the importance of criteria (based on the Hadith) for selecting leaders or rulers. At the same time, Hadith concerning the qualities necessary to be worthy to lead prayers as 'imam' are also discussed (AlMarbawi vol.2:127)

The Prophet declares: The person who is best versed in the recitation of the Qur'an, should lead the prayer; but if all those present are equally versed in it, then the one who has most knowledge of the Sunnah; if they are equal in that respect too, then the one who has emigrated (to Medina) first, if they are equal in this respect also, then the oldest of them. No man should lead another in prayer where the latter has authority, or sit in his house without his permission (AMarbawi vol.2:122-126).

In another narration:

The Prophet said, one who is most senior in accepting Islam, should lead the salat (prayer) (A-Marbawi vol.2:127128).

For al- Marbawi, these Hadith therefore illustrate that the order of priority for the appointment of imam (one who leads the prayers) should go to those qari' (reciters of the Qur'an) who can clearly articulate their recitation of the Qur'an; who are pious in nature, and who act faithfully according to those teachings. The Prophet must be seen to apply these teachings as 'a reference point' in the acquisition of areas of knowledge which is outside Islam. Furthermore, he must not be a non-practising Muslim.

These Hadith are also used as added 'symbolic' selection criteria in ranking the hierarchy of religious scholars (A- 
Marbawi vol.13:105) and the rulers in the Muslim community. To this end, he draws up specific characteristics which possible candidates for the ruler must display to be 'legitimised' under Sharicah as laid down by the Prophet:

1. Rulers or leaders must be Muslim.

2. The ruler must be male. This condition is based on the Hadith in which the Prophet states that a nation would not profit under a woman leader.

3. He must be knowledgeable in Islamic teaching, and be possessed of wisdom and judgement to make sound independent decisions and stand firm by those decisions.

4. He must be just, have good morals, and be trustworthy.

According to this elaboration of the Prophet's words, then (as set out in Hadith, vol.2, pages 127-128), al-Marbawi crystallises two main 'parameters' for 'conditions' to be met by prospective rulers (A-Marbawi vol.2, p.127-128):

i) The first is the relevant high-level qualities, virtues, wisdom and judgement for the position to which he is appointed, and the second is his capacity for discharging responsibilities thereof. For example, a ruler should primarily possess the ability to maintain law and order and to establish justice;

ii) Secondly, he should be endowed with sufficient dynamism and vision to confront new demands and situations. This basic principle applies to every official, whether in the capacity of governor, minister, or advisor (AMarbawi vol.2, p.127-128).

\section{A Warning to Rulers}

Clearly, the commentary of Bahr al-Madhi serves to legitimize and sanctify the authority of the ruler within the wider political order; it also issues a stern warning to those in authority. Bahr al-Madhi of al-Marbawi states:

The Prophet declares: "He who does not look after his subjects with goodwill and sincerity, will be deprived of the fragrance of Jannah (Heaven)" (A-Marbawi vol.10, p.36) .

Another Hadith of the Prophet: "A ruler (who having control over the affairs of the Muslims), does not strive diligently for their betterment and does not serve them sincerely, will enter al-Nar (Hellfire)" (A-Marbawi vol.10:36) .

Al-Marbawi thus stresses that the designated ruler is accountable to Allah for the extent of his diligence for the 'betterment' of the Muslim people. The responsibility for wise dealings in Muslim affairs is therefore heavy. It is for this reason that the lesson in this Hadith contains a warning. Those leaders who violate the trust which is placed in them are 'forbidden form entering Jannah'.

An example of such violation of trust is the giving or acceptance of bribes, which is forbidden in Islam. The ruler must not therefore be tempted to use money to procure special favours, or encourage dishonest practices, as is seen in the Prophet's curse:

The Prophet cursed the one who bribes and the one who takes bribes (A-Marbawi vol.10:49). 0 my brothers! This is often practice in our country nowadays, a bribe should never be given and it is a big sin (A-Marbawi vol.10:49).

\section{The Categories of Rulers}

The wisdom, guidance and justice expected in the sultan or ruler is further emphasised through the 'two categories' identified in the Hadith. For every three rulers, only one will enter Heaven (A-Marbawi vol.10:37). Only those who treat their subjects with gentleness, who are 'well-wishers' and provide their people 'with justice', are worthy of the prayers of the believers. Those who consider only their own interest and who do not uphold wisdom or justice for their subjects will not enter Heaven.

Beyond this, rulers are counselled to adhere to justice, uprightness and equity because this will endear them to Allah Himself. On the basis of the great trust and authority which is rested in the ruler, we are therefore told that rebellion against him is disallowed unless he commits a flagrant act of disbelief, and does not abide by the duties of Islam (particularly if he neglects the duty of prayer) (A-Marbawi vol.10:34-39).

In brief, then, these elements of al-Marbawi's commentary ('the duties and responsibilities of the rulers', 'the obedience and disobedience to rulers', 'a warning to rulers', 'the prerequisites to becoming rulers' and 'the categories of rulers' sub-headings) provide a political model which is rooted in the purity of the truth as received directly from Allah by the Prophet. Taken as a whole, therefore, the commentary acts as a clear and authoritative guide for political leadership in the modern context of polemical debate. Above all, the texts issues a stern warning to those holding positions of authority that personal (as opposed to institutional legitimacy) must be rooted in piety, humility and a sincere intent to govern in the interest of the Malay community. 


\section{Conclusion}

To conclude this article, the translation and the commentary of Bahr al-Madhi can be understood as a scriptural justification of the political stance of Malay's current leadership. Its discussion of a just society, leadership, rulers, and sultan establishes a textual basis for some of the central principles of the Islamic political teaching. In addition, the clear guidelines across all areas of human conduct contained in this great text represent a vital resource for the purpose of constructing the ideal Islamic state. Its principles are based on the purity of the Prophet's example as contained in the Hadith.

It is therefore affirmed that a return to these principles is vital to rectify current political departures from the fundamental truth discussed, such as the drinking of alcohol, the taking of bribes at leadership level, and so on. The writing of al-Marbawi $\Leftarrow$ thus has a vital role to play as transmitters of authoritative Hadith teachings to the Malay community, as set out with clarity by this great scholar.

\section{References}

Al-Edrus, Syed Muhammad Dawilah. 1993. The role of Kitab Jawi in Islamic thought in the Malay Archipelago with special reference to Umm al-Barahin and the writings on the twenty two attributes. Ph.D Thesis. University of Edinburgh.

Al-Marbawi, Muhammad Idris 'Abd al-Rauf al-Azhari. N.d. Mukhtasar sahih al-tirmidhi wa sharh bi lughat al-jawi al-Malayu al-musamma bahr al-madhi.22vols. Egypt: Dar al-Fikr.

cAbd Allah Zakaria Ghazali. 1980. Agama dan kebangkitan anti-British di Tanah Melayu. In. Khoo Kay Kim (ed.). Tamadun Islam di Malaysia. Kuala Lumpur: Persatuan Sejarah Malaysia.

Fauzi Deraman, Karya-karya Hadith dalam tulisan Jawi, Journal Usuludin, December 1999, no.10, pp.163-173

M.R.Woodward. 1993. Textual exegesis as social commentary: religious, social and political meanings of Indonesian translations of Arabic Hadith texts. Journal of Asian Studies. vol.53 (3). pp.565-583.

Mohamed Nawab Mohamed Osman, towards a history of Malaysian ulama, Singapore: S. Rajaratnam School of International Studies, p.10.

Mohd Nor Ngah. 1983. Kitab Jawi: Islamic thought of the Malay Muslim scholars. Singapore: Institute of the Southeast Asian Studies.

Muhammad Azizullah, Glimpses of the Hadith, The Crescent Publications:n.p.,1973.

P.Riddell.2000. Islam and the Malay-Indonesian world: transmission and responses. Honolulu: University of Hawaii Press.

Rahimin Affandi Abd. Rahim, traditionalism and reformism polemic in Malay-Muslim religious literature, Islam and Christian - Muslim Relations, vol.17, no.1, January 2006, pp.93-104.

Robert W.Hefner and Patricia Horvatich, Islam in an era of Nation-States, University of Hawaii Press, 1997.

Syed Abdul Hasan cAli Nadwi. N.d. Relevance of the Hadith of the Prophet to religious and social life in the modern times, in the place of Hadith in Islam. Proceeding of the Seminar on Hadith.

T. Iskandar, Nuruddin Ar-Raniri's Bustanu's Salatin, Kula Lumpur: Dewan Bahasa dan Pustaka, 1966.

Wan Sabri Wan Yusuf, Shayuthi Abdul Manaf \& Nadzirah binti Muhammad, Shaykh Mustafa Abdul RahmanMahmud (19181968)twentieth century Malay Qur'anic interpreter, in Muhammad@Mohd.Som Sujimon (ed.), Monograph on selected Malay intellectuals

Zayn al-cAbidin Muhammad al-Fatani, Kashf al-Litham, Cairo,1308AH/1890AD.

http://www.ibnyahya.com/World/marbawi.htm.

http://www.sunnah.org/history/Scholars/imam tirmidhi.htm

http://www.msapubli.com/affiliated/Html/categories/Jamiatul_ulama/tirmidhi01.html 